\title{
Elections, Contestation, and Democracy
}

\author{
Jeffrey C. Isaac
}

$\Lambda$ s I write this Introduction on June 1, 2013, Turkey is experiencing a fourth day of street demonstrations against the government of Prime Minister Recep Tayyip Erdogan and his Islamist-based Justice and Development Party. What began as a protest of government plans to construct a shopping mall on the site of an Istanbul green space has escalated into a broader protest of Erdogan's decade-long tenure in office. The government has thus far responded violently, and the protests have intensified. A Reuters news report summarizes the crisis:

Erdogan vowed to push ahead with [his] plans. ... "Every four years we hold elections and this nation makes its choice," he said in a speech broadcast on television. "Those who have a problem with government's policies can express their opinions within the framework of law and democracy. ... I am asking the protesters to immediately end these actions," he said. The opposition accused him of behaving like a dictator. "Tens of thousands are saying no, they are opposing the dictator. ... The fact that you are the ruling party doesn't mean you can do whatever you want," said Kemal Kilicdaroglu, leader of the main opposition Republican People's Party (CHP). Erdogan has overseen a transformation in Turkey during his decade in power ... and remains by far the country's most popular politician. But critics point to his authoritarianism and what they say is his religiously conservative government's meddling in private life in the secular republic, accusing him of behaving like a modern-day sultan.

These events will obviously continue to unfold, and they will no doubt fuel a range of political science perspectives. What is clear is that participants in these controversies-protesters, political elites, and journalistic commentators-invoke themes that are central to political science: the practical and normative significance of elections; the relationship between electoral forms of legitimacy and other claims of legitimacy; the relationship between legal and extra-legal, and normal and extraordinary forms of political action; and the relationship between electoral democracy and authoritarianism. Numerous times in recent years our journal has focused on these themes (most recently in our December 2012 issue), because they are central both to contemporary political contestation and to contemporary political science. And so we return to them again here.

Each of our first three research articles extends an important ongoing research program on the comparative politics of authoritarianism and democratization. Dan Slater and Joseph Wong's "The Strength to Concede: Ruling Parties and Democratization in Developmental Asia" centers on an interesting apparent paradox-that some of the world's strongest single-party authoritarian regimes have not resisted democratization, but have sought to incorporate and perhaps even to embrace it. Slater and Wong argue that: "authoritarian ruling parties can thus be incentivized to concede democratization from a position of exceptional strength as well as extreme weakness." They call this "conceding-to-thrive," and they analyze the logic of this strategy and the conditions under which it makes most sense, and then offer analytic narratives of three Asian states where ruling parties have democratized from varying positions of considerable strength-Taiwan, South Korea, and Indonesia—and three Asian states "where ruling parties have not yet conceded democratization despite being well-positioned to thrive were they to do so: Singapore, Malaysia, and the world's most populous dictatorship, China." The piece combines theoretical rigor with the kind of empirical detail characteristic of the best area studies research.

Ruchan Kaya and Michael Bernhard's "Are Elections Mechanisms of Authoritarian Stability or Democratization? Evidence from Postcommunist Eurasia" also analyzes the complex politics of authoritarian elections and their democratizing potential, this time with a focus on post-Communist Eurasia. Kaya and Bernhard position themselves between theorists of "electoral authoritarianism" - such as Ellen Lust, Jennifer Gandhi and Adam Przeworski, and Steven Levitsky and Lucan Way-who regard elections "as a stabilizing mechanism for authoritarian regimes," and theorists of "democratization by elections" - such as Staffan Lindberg, Mark Beissinger, and Valerie Bunce and Sharon Wolchik-who argue "that elections are dangerous for authoritarian leaders, and ... can establish a path to incremental democratization." Their piece tests these theories through a combination of large-n statistical analysis and a paired case study of Slovakia and Belarus, finding "little evidence that holding of elections in themselves serves as a catalyst for democracy." At the same time, their findings are "consistent with the claim that mobilization against authoritarian incumbents can liberalize and even democratize electoral authoritarian regimes when the opposition is 
coordinated and unified. However ... the ability to demobilize supporters of the incumbent to negate both the residual organizational advantages they may have inherited from the old regime as well as more contemporary neo-patrimonial sources of support, is equally important."

Kaya and Bernhard note that "the adoption of the institutions of democracy and their transformation into tools of a new form of plebiscitary authoritarian rule is a novel, widespread development that marks the post-Cold War period as unique and challenges our longstanding understanding of the role of elections in politics." They suggest that this has had particularly troubling consequences for much of the post-Soviet region, where the much-vaunted "Color Revolutions" have stalled, and "competitive authoritarianism is a viable, probably long-term, regime form." Even more importantly, they observe that "[p]oliticians in a number of democratic countries ... have begun to use some of the tricks from the competitive authoritarian arsenal. . . . Measures that reduce uncertainty hold attractions for self-interested politicians. Dirty tricks like gerrymandering, rewriting rules to provide advantages in media time or campaign funding, neutralizing countervailing powers, and intimidating or demoralizing the supporters of opponents constitute threats to democracy even if enacted under rule of law." At the heart of Kaya and Bernhard's argument is the idea that electoral processes are the site of ongoing contestation between political elites and civil society actors under authoritarian circumstances, during transitions, and even under more democratic conditions.

Karrie J. Koesel and Valerie J. Bunce's "DiffusionProofing: Russian and Chinese Responses to Waves of Popular Mobilizations against Authoritarian Rulers" focuses on a related question-whether and how authoritarian rulers deliberately and proactively seek to deter, constrain, and repress forms of contestation that jeopardize their rule. Bunce has long been a prominent theorist of democratic diffusion. (Indeed, her book co-authored with Sharon L. Wolchik, Defeating Authoritarian Leaders in Postcommunist Countries, is reviewed in this issue and discussed below.) In this piece she turns, with Koesel, to the analysis of what they call diffusion-proofing - the strategic efforts of rulers to limit the "contagion effects" of democratic contestation elsewhere. Koesel and Bunce outline a variety of diffusionproofing measures, from efforts to control and frame public communication about uprisings elsewhere to the demobilization of civil society to the coercion and cooptation of key opposition constituencies to more manifest forms of repression. They then analyze the ways that the Russian and Chinese regimes have employed these measures in order to contain the democratic diffusion effects associated with the early 2000's Color Revolutions in postSoviet Eurasia and the 2011 Arab Spring.

Koesel and Bunce's analysis is usefully read alongside three discussions featured in our Review section: Kellee Tsai's review essay on the political economy of the Chi- nese state and its connection to the resilience of Chinese authoritarianism; the book symposium on Stefan Hedlund's Invisible Hands, Russian Experience, and Social Science: Approaches to Understanding Systemic Failure, with commentaries by Ellen Carnaghan, Stephen E. Hanson, and Peter Rutland; and the Critical Dialogue between Tatiana Kostadinova and Reinoud Leenders on political corruption. It also links strongly to András Bozóki's "Dictators and Rebellious Civilians," a major review essay on four important new books on civil resistance and authoritarian responses: Bruce Bueno de Mesquita and Alastair Smith's The Dictator's Handbook: Why Bad Behavior Is Almost Always Good Politics; Bunce and Wolchik's Defeating Authoritarian Leaders in Postcommunist Countries; Erica Chenoweth and Maria J. Stephan's Why Civil Resistance Works: The Strategic Logic of Nonviolent Conflict, and William J. Dobson's The Dictator's Learning Curve: Inside the Global Battle for Democracy. As Bozóki writes: "The books discussed here all call attention to the fact that a wide gray zone has recently opened up between democracy and dictatorship, a zone occupied by hybrid or mixed regimes. Both the autocratic leader and the democratic opposition try to use the narrow public arena existing in these systems to their own advantage; that is, political struggle is defined in terms of competing system alternatives. Not only democrats from various countries, but also dictators can learn from each other. The 'domino effect' often seen in international politics may work in two ways. In many cases, well-established democratic institutions do not offer a guarantee against the rise of strongmen when such leaders use the system's weaknesses in bad faith. Just as there are 'best practices' for the upholding and expanding of a democratic system, there are also those for its destabilization, and today efforts to spread these destructive practices are seen on a global scale." Bozóki, a prominent theorist of democracy and a Hungarian public intellectual (and former President of the Hungarian Political Science Association) approaches these dynamics from the perspective of one who has experienced them first-hand. Bozóki participated in the 1989 Hungarian Roundtable talks as an associate of the liberal Alliance of Free Democrats (chronicled in his edited volume, The Roundtable Talks of 1989: The Genesis of Hungarian Democracy); served as Hungarian Minister of Culture in 2005-06; and he is a frequently published commentator on Hungarian affairs. His review essay presents a wide-ranging discussion of the ongoing challenges of democratic transition and consolidation in post-Communist Europe, and concludes with a penetrating discussion of the current crisis of Hungarian democracy.

As many of the above-mentioned pieces make clear, electoral institutions feature prominently in these political narratives, both as determinants and as objects of political contestation. Readers will recall that our March 2013 issue featured an important discussion of this theme, 
G. Bingham Powell, Jr.'s 2012 APSA Presidential Address, "Representation in Context: Election Laws and Ideological Congruence Between Citizens and Governments." We are pleased to feature here a follow-up discussion, a symposium on "Between Science and Engineering: Political Science, Electoral Rules and Democratic Governance," edited by Perspectives Associate Editor Mala Htun in collaboration with G. Bingham Powell. Htun chaired Powell's APSA Presidential Task Force on Electoral Rules and Democratic Governance, and this symposium includes short original contributions summing up the work of that Task Force, co-authored respectively by Htun and Powell; Karen Ferree, G. Bingham Powell, and Ethan Scheiner; Mona Lena Krook and Robert Moser; Matthew S. Shugart; John Carey and Simon Hix; Andrew Rehfeld and Melissa Schwartzberg; and John Carey, Simon Hix, Mala Htun, Shaheen Mozaffar, G. Bingham Powell, and Andrew Reynolds. Perspectives does not normally run symposia on Presidential Task Forces. We have made an exception in this case because the cancelation of the 2012 APSA Conference in New Orleans also forced the cancellation of the events associated with the Task Force's work. The symposium, adeptly coordinated by a member of our editorial board, fits wonderfully with the themes featured in this issue.

By and large, the analysis of U.S. politics by American political scientists tends to be insulated from broader political science discussions of democracy and authoritarianism in comparative perspective- a state of affairs criticized in Alfred Stepan and Juan Linz's "Comparative Perspectives on Inequality and the Quality of Democracy in the United States," a December 2011 Perspectives review essay. It is worth noting that the Democracy Index 2012: Democracy at a Standstill, recently published by the Economist, ranks the United States twenty-first in terms of the quality of its democracy, with emphasis placed on the "low quality" of the "functioning of its government."

This issue contains two research articles that bear on this assessment. Daniel Tichenor's "Historical Set Points and the Development of U.S. Presidential Emergency Power" brings a historical perspective to discussions about presidential power that have been renewed in the wake of the Bush administration's responses to 9/11 and that have received increasing, recent attention due to a range of Obama-administration policies, most notably drone attacks and the targeted assassination of "terror" suspects. Tichenor argues that "the development of presidential emergency power reflects the potential for early executive choices to be repeated and legitimated over time, laying dormant as a 'loaded weapon' to be used by future executives in similarly urgent circumstances." It develops this theme through careful comparison of the wartime policies of four U.S. presidents-Abraham Lincoln, Franklin Delano Roosevelt, George W. Bush, and Barack Obama. As Tichenor writes: "Obama may have aspired to revive the Lincolnian model of a circumspect Commander in Chief and to fun- damentally dismantle Bush's counterterrorist regime, but his options were ultimately quite limited. The development of presidential emergency power has become a twoedged sword in recent years, presenting significant opportunities for Bush's assertion of sweeping unilateral powers and formidable impediments to Obama's initial designs to restrain them. After more than a decade of executive action in response to $9 / 11$, it has become clear that presidential emergency power has evolved from a 'loaded weapon' to an arsenal that is open for business." In this way, Tichenor's piece contains striking parallels to the discussions, by Kaya and Bernhard and by Bozóki, of the ways that even democratically elected political leaders exercise their powers to erode aspects of democratic accountability. It would surely be a mistake to ignore the differences in situation and purpose between U.S. President Obama and Hungarian Prime Minister Viktor Orban. At the same time, it would also be a mistake to ignore obvious points of comparison.

Jennifer Merolla, S. Karthick Ramakrishnan and Chris Haynes's “'Illegal,' 'Undocumented,' or 'Unauthorized': Equivalency Frames, Issue Frames, and Public Opinion on Immigration" addresses a different challenge facing U.S. democracy - that of devising an immigration policy capable of addressing the fact that " $[t]$ oday, there are an estimated 11 million unauthorized immigrants in the United States, most of whom are long-term residents of the United States and unlikely to return to their home countries in mass numbers." As Merolla, Ramakrishnan, and Haynes point out, incorporating this population has important policy and labor market ramifications, but it also relates to fundamental issues of democratic inclusion. Their article centers on the framing of the issue in news coverage and popular discourse. Employing both innovative experimental methods and media content analysis, Merolla, Ramakrishnan, and Haynes compare the impact of discourse focused on immigrants with the impact of discourse centered on policy alternatives. And they find, interestingly, that "if the primary goal of framing is to move public opinion on immigration policy, groups on either side of the issue divide would find it more effective to focus on efforts to frame policies rather than to battle over the terms used to describe those without legal status." At the same time, they also note that "changes in citizenship regimes require sustained social movement activity, and the framing of immigrants as 'belonging' and deserving of rights can certainly play a role in the long term. Advocates in the United States may thus find it fruitful to go beyond simply trying to 'drop the I-word' and attempt even more ambitious campaigns to reframe how undocumented immigrants are perceived, as equal members of society deserving of the same autonomous rights."

Yet unfortunately, the problems of "government functioning" noted in the Economist's Democracy Index are 
likely to continue to impede serious immigration reform in the United States. These problems are the focus of Morris Fiorina's review essay on "America's Polarized Politics: Causes and Solutions." Fiorina reviews three recent books that critique the rise of hyper-partisanship and its contribution to policy gridlock: E.J. Dionne, Jr.'s Our Divided Political Heart: The Battle for the American Idea in an Age of Discontent; Amy Gutmann and Dennis Thompson's The Spirit of Compromise: Why Government Demands it and Campaigning Undermines It, and Thomas E. Mann and Norman J. Orenstein's It's Even Worse Than It Looks: How the American Constitutional System Collided with the New Politics of Extremism. Surveying the range of philosophical, historical, and institutional explanations furnished by these authors, Fiorina observes that the sources of political polarization and gridlock run deep in both Democratic and Republican parties; that this state of affairs is alienating to a wide swatch of the U.S. public; and that a "chaotic politics" is likely to continue until a "new governing majority-when and if it arrives," is capable of effecting institutional reform and a new public philosophy.

\section{A Comment on Books}

This issue of Perspectives contains a special Review section that features a range of political science books on the theme of "Elections, Contestation, and Democracy." The book section also includes three Critical Dialogues, each of which brings into conversation political scientists writing on similar topics from different perspectives. It includes an "Undisciplined" symposium on Invisible Hands, Russian Experience, and Social Science, a book written by economist Stefan Hedlund. It also includes over 75 conventionally formatted single, double, and triple book reviews. Almost half of every issue of Perspectives is dedicated to our Review section. This structure of the journal is something that we inherited, for when Perspectives was created, it was decided to move the book reviews, which had previously been published in the APSR, to Perspectives, and to open up the new journal to a range of writing formats. We inherited this structure, and we also embraced it. Indeed, I assumed the position of Editor in Chief of the entire journal after having served for four years as the Book Review Editor under the editorship of my predecessor, James Johnson. During my tenure as Book Review Editor we made a conscious decision to innovate with this section by creating new formats-Critical Dialogues, book symposia, different kinds of thematic review essays, and Review Editor Introductions highlighting common themesand trying to make the "back end" of Perspectives a space for lively conversation across conventional subfield and methodological divides in the discipline. When I was offered the editorship of the entire journal, I agreed to accept this position on the basis of a clearly defined vision that was grounded in our experience with the Review section, and I was committed to editing the entire journal as a whole. We "branded" the journal as "A Political Science Public Sphere," and worked hard to nurture synergies between the research articles and essays published in the journal's "front end" and the reviews and book discussions published in its "back end." My staff and I have devoted enormous energy to this approach to the journal, with the strong support of our dedicated Editorial Board and with the support of the APSA Council. These efforts were recognized by the 2011 Performance Review Committee that recommended the extension of our editorial tenure. But in my view the most important "recognition" of this approach is the fact that we continue to enjoy the enthusiastic participation of many hundreds of authors and reviewers every year, and to produce a publication that includes a wide range of excellent contributions.

At the heart of the journal as it has come to be structured, read, and appreciated within the profession, is the deliberate effort of our editorial team to discern, nurture, and publicize complementarities, synergies, and broad thematic interests that might otherwise be insufficiently recognized by our increasingly specialized academic life. Our entire range of formats is dedicated to this end. We have nurtured the production of research articles that are rigorous, rigorously peer-reviewed, and at the same time written and framed more broadly than conventional research articles. We have nurtured a range of conversations about political science books, and promoted conversations among our articles and our book reviews and essays. These connections have been essential to our vision of "a political science public sphere."

It is sometimes overlooked how central our Book Review section is to this effort. I have been a professional political scientist for over thirty years. I am well acquainted with the still widely accepted notion that book review assignments are convenient means of getting a free book that you want to read, so that you can then dash off a thousand-word commentary during breaks from "real" research and writing. For the past 8 years we have worked tirelessly, and successfully, to counter this unfortunate notion. Books are important, and so attention to them is important. While promptly published scholarly articles are also important, the book remains the only format that allows scholars, in every field and from every perspective, to take the time and 
space to develop an argument in depth. Books are at the heart of political science. Important books help to create new research agendas. The names Dahl, Fenno, Katzenstein, Olson, Ostrom, Putnam, Rawls, Riker, or Skocpol do not evoke journal articles. Each evokes an important book, and typically more than one of them. Every year many hundreds of new political science books containing new political science perspectives are published. We all know this. The Book Exhibit at the annual APSA conference is one of the main attractions for almost everyone. These books seek and deserve more than mere citation. They deserve serious discussion in a serious scholarly context. They deserve well-written reviews that are carefully edited by editors who work with reviewers, and prompt them to think a bit more broadly, and to view their book reviews as real scholarly engagements. Such reviews do much more than publicize and provide shortcuts to books that readers might not otherwise know about. They engage the books and make them truly a part of serious scholarly dialogue.

But there is something else: These reviews make their authors part of a serious scholarly dialogue. Most of our colleagues do not work at research-intensive universities. Most of them spend most of their time teaching, often with heavy loads, either as tenured or tenure-track professors at teaching institutions, or as adjuncts and part-time academic workers. For many of our colleagues, the chance to write a fine book review, to have it seriously engaged by an editor, and to have it pub- lished in a "flagship research journal" is one of the only significant opportunities they may have to write and to publish in a given year. Every year Perspectives on Politics publishes hundreds of reviews written by a very wide range of scholars with a wide range of institutional affiliations. We are very serious about the range and diversity of the contributors to our book review section. One reason is because it allows our journal to reach broadly and to include many of its readers as contributors. This "community-building" function of Perspectives is very important, for a scholarly community ought to be linked by inclusive scholarly conversation. But this kind of inclusion is also important in an epistemic sense. For it "enforces" a breadth of scholarly perspective, and brings expert discourses into conversation with more generalist perspectives, to the benefit of the kind of true critical engagement that is the heart of the scientific enterprise.

We are excited about the range of formats contained within Perspectives and the way that they work together to project a vision of scholarly and intellectual seriousness. We are also grateful to the many colleagues who support us in these efforts and embrace the chance to be active participants in and contributors to the journal and its many formats. We continue to receive a growing number of article submissions, and we have many exciting book review special features planned in the coming issues. As we move forward, we welcome your ideas, your suggestions, and your ongoing contributions. 


\section{Statement of Mission and Procedures}

Perspectives on Politics seeks to provide a space for broad and synthetic discussion within the political science profession and between the profession and the broader scholarly and reading publics. Such discussion necessarily draws on and contributes to the scholarship published in the more specialized journals that dominate our discipline. At the same time, Perspectives seeks to promote a complementary form of broad public discussion and synergistic understanding within the profession that is essential to advancing scholarship and promoting academic community.

Perspectives seeks to nurture a political science public sphere, publicizing important scholarly topics, ideas, and innovations, linking scholarly authors and readers, and promoting broad reflexive discussion among political scientists about the work that we do and why this work matters.

Perspectives publishes work in a number of formats that mirror the ways that political scientists actually write:

Research articles: As a top-tier journal of political science, Perspectives accepts scholarly research article submissions and publishes the very best submissions that make it through our double-blind system of peer review and revision. The only thing that differentiates Perspectives research articles from other peer-reviewed articles at top journals is that we focus our attention only on work that in some way bridges subfield and methodological divides, and tries to address a broad readership of political scientists about matters of consequence. This typically means that the excellent articles we publish have been extensively revised in sustained dialogue with the editor-me-to address not simply questions of scholarship but questions of intellectual breadth and readability.

"Reflections" are more reflexive, provocative, or programmatic essays that address important political science questions in interesting ways but are not necessarily as systematic and focused as research articles. These essays often originate as research article submissions, though sometimes they derive from proposals developed in consultation with the editor in chief. Unlike research articles, these essays are not evaluated according to a strict, doubleblind peer review process. But they are typically vetted informally with editorial board members or other colleagues, and they are always subjected to critical assessment and careful line-editing by the editor and editorial staff.

Scholarly symposia, critical book dialogues, book review essays, and conventional book reviews are developed and commissioned by the editor in chief, based on authorial queries and ideas, editorial board suggestions, and staff conversations.

Everything published in Perspectives is carefully vetted and edited. Given our distinctive mission, we work hard to use our range of formats to organize interesting conversations about important issues and events, and to call attention to certain broad themes beyond our profession's normal subfield categories.

For further details on writing formats and submission guidelines, see our website at http://www.apsanet.org/ perspectives/ 